This is an open access article under the CC BY-NC-ND license

Issue IV, 22 November 2021

e-ISSN 2707-9481

Institute of Metallurgy and Ore Beneficiation, Satbayev University, Almaty, Kazakhstan

ISBN 978-601-323-252-2

https://doi.org/10.31643/2021.04

\author{
Gulzhaina K. Kassymova \\ Institute of Metallurgy and Ore Beneficiation, \\ Satbayev University; Abai Kazakh National \\ Pedagogical University, Kazakhstan \\ E-mail: g.kassymova@satbayev.university \\ ORCID ID 0000-0001-7004-3864 \\ Farid R. Vafazov \\ I.V. Panfilov Kazakh-Russian Specialized \\ School-Lyceum №54, Almaty, Kazakhstan
}

\author{
Fathimah D. Pertiwi \\ Budi Mulia Dua Senior High School, Indonesia \\ Email: fathimahday@bmd.sch.id \\ ORCID ID: 0000-0002-4604-3167
}

\section{Aigul I. Akhmetova}

Abai Kazakh National Pedagogical University; University of International Business, Kazakhstan

E-mail: aig.31@mail.ru

ORCID ID: 0000-0002-9292-5515

\author{
Guldana A. Begimbetova \\ Abai Kazakh National Pedagogical University; Gymnasium №62, Kazakhstan \\ E-mail: danka-0810@mail.ru \\ ORCID ID: 0000-0002-0435-1014
}

\title{
Upgrading Quality of Learning with E-Learning System
}

\begin{abstract}
This article studies different ways of learning. Behavioral, cognitive, constructivist learning, multiple learning styles, e-learning, and brain-based learning are interrelated with each other and teachers should ensure that all students should be involved in all types of learning styles to get learning outcomes. The Covid-19 pandemic has forced governments around the world implement policies to limit face-to-face meetings with community activities. This makes community activities carried out virtually. It also happens in education system, teaching and learning activities which are usually carried out in classes face to face, this time have to use the internet as a learning medium. E-learning environments create lessons interactive. Knowledge is integrated from many different sources when students are learning something. The result of this study by analyzed ways of learning is five learning approaches. The stages of learning approaches are student to be active, engaged in the learning process, increase previous knowledge, explore the situation, and to be motivated. Nevertheless, use of the internet for learning or e-learning also cannot be separated from various deficiency and emerging issues within the higher education context.
\end{abstract}

Keywords: education, e-learning, students, approach, and teachers.

Cite this article as: Kassymova, G.K.; Vafazov, F.R.; Pertiwi, F.D.; Akhmetova, A.I.; Begimbetova, G.A. (2021). Upgrading Quality of Learning with E-Learning System. Challenges of Science. Issue IV, 2021, pp. 26-34. https://doi.org/10.31643/2021.04

\section{Introduction}

As Skinner (1958) stated that education must be efficient for every student. Till to date, Skinner's observation of school education has not lost his relevance yet (Flindt, 2005, p. 61). The curriculum must be revised and learning materials must be improved for efficient learning.

Student-centered learning strategies, models and methods will encourage the development of knowledge and burnish students' skills. According to Wagner in Suartama (2014), knowing the global development, know information and remember facts are not enough for students, but they must be able to think critically, solve problems, and have skills in communicating and working together. In addition, students must also be able to adapt, have the initiative, and be able to access and analyze information.

The Covid-19 pandemic has forced governments around the world implement policies to limit face-toface meetings with community activities. This makes community activities carried out virtually. It also 
happens in education system, teaching and learning activities which are usually carried out in classes face to face, this time have to use the internet as a learning medium.

The use of the internet as a learning medium requires schools, teachers and students to be able to use modern information and communication technology in order to achieve the purpose of learning. Schools need to make policies in determining the right media or e-learning to be used in learning activities. Elearning is learning that utilizes the support of internet technology. In e-learning, teachers do not just upload learning materials that can be accessed online by students, but teachers also evaluate, establish communication, collaborate, and manage other learning aspects (Suartama, 2014). Teachers and students must be able to understand the concept and use of e-learning to create active, innovative, creative, effective, and fun learning. Through e-learning, learning materials can be accessed anytime and from anywhere. In addition, the material can be enriched with various learning resources including multimedia and quickly updated or edited by the teacher.

E-Learning provides a flexible learning environment, it requires more than just transforming learning material into web-based environments and learning online. Successful implementations of e-learning environments require an understanding of the technology and pedagogy integration for learning to take place effectively (Kahiigi, Ekenberg, Hansson, Tsubira, Danielson, 2008). An effective e-learning strategy needs to focus on effectiveness as well as efficiency, and it needs to integrate all the available technologies for ensuring a capable organization. Strategies that focus on one-for-one substitution of e-learning for platform training are ultimately doomed to failure (Rosenberg, 2002. According to Ally in Suartama (2014), the development of learning materials in e-learning needs to consider three well-known learning theories, namely: behaviorism, cognitivism, and constructivism. These three theories can be used as a taxonomy of learning, for example behaviorism theory to teach facts (what), cognitivism theory to teach processes and principles (how), and constructivism theory to teach higher intellectual activity (why).

\section{Research methodology}

Behavioral learning. Learning is the acquisition of new behavior. John B. Watson used this term in the realm of educational psychology for the first time in the USA. This method of learning is called conditioning. There are two types of conditioned learning. The first one is called classical conditioning. Experiment on classical conditioning was initially conducted by a Russian psychologist, Ivan Pavlov with means of a bell to make dogs salivate before feeding them. Pavlov identified 4 stages of the process of conditioning: acquisition, extinction, generalization and discrimination. Another type of behavioral learning is called operant conditioning. B. F. Skinner is the most famous psychologist for this type of learning. He used a lever device which was a reward system for animals; as a result of pressing a lever in the box, animals got a pellet of food. This way of learning is more powerful and flexible because of its positive and negative reinforcement, reward and shaping processes. Skinner states that immediate feedback has great importance for reinforcement of programmed learning (Alan Pritchard, 2009, p. 5-13). For instance, nowadays e-learning materials enable such conditions to indicate whether a student is successful with the question reply or not, by active flashing on the computer display; self-paced e-learning has a potential to be powerful because a student studies materials in bite-sized pieces on his own pace.

Constructivist learning. Cognition is a high level of behavior. It is about to think and understand a situation and accordingly act. Cognitive learning is related to the mental construction (Arpentieva et al., 2021). Cognitive learning is a mental process such as learning, perceiving, remembering, speaking, solving problems, critical thinking, analyzing and so on (Shanty et al., 2018; Mustapha et al., 2019). Constructivist learning takes place when new information is built and added to the current knowledge, understanding and both mental and physical skills. Prior knowledge plays a key role in learning. Learners are able to learn something when they are active in the learning process. Constructivist learning was initially developed by Jean Piaget. He studied 4 stages of child cognitive development; this formed the basis of the constructivist movement. He concluded that students should actively construct their knowledge. Learning is an active mental process (Woolfolk, 1993). A socially constructive approach takes place in pair conversation. Learning occurs by anyone who is more knowledgeable in different environments, not only in the classroom. Any social interaction may lead to the learning process. Vygotsky's work offered proximal development, which means that a learner accumulates more theoretical knowledge by a more knowledgeable person and may act more effectively (Alan Pritchard, 2009, p. 17-29). 
So, constructivism is a thought or view of the formation of knowledge with the active participation of learners (Candra, \& Retnawati, 2020). Thus, constructivism is considered as the process of acquiring knowledge through the active adaptation of individuals to the environment (Piaget, 1936). Moreover, constructivism is part of the process of social interaction outcomes as knowledge construction (Vigotsky, 1978). In the e-learning environment, students should be independent learners, which means that they will be active learners and interact with the virtual environment. Researchers state that online materials are widely accepted as a useful and effective tool, especially, in the field of language acquisition. In addition, digital technology increases the interest and motivation of students in the social sciences (Lai \& Lin, 2020). Prior knowledge and social interaction are a crucial part of learning.

Learning styles. To open students' full potential, it is also essential to rely on Howard Gardner's multiple intelligence theory (Gardner, 1993). Students should be taught by the different ways of learning to get learning outcomes. Nowadays, e-learning may enable such learning multiple environments by means of Internet resources. For instance, there was a case study about the successful learning outcomes of online language proficiency in the EF English Live online platform for adult education (Kenzhaliyev et al., 2020; Kassymova et al., 2020). This study concluded that it is important to have a piece of prior knowledge and intrapersonal motivation in order to learn online. Online education is useful for personal self-development as well as cognitive development (Kassymova et al., 2020). Once students become actively engaged in elearning environments, they develop a sense of control and motivation to self-development. There are many learning styles for individuals and different models depending on the learners' personalities. For instance, the Honey-Mumford Model which includes 4 stages such as activist, reflectors, theorists and pragmatists. Table 1 gives a brief pictorial explanation of different ways of learning. Problems can arise for teachers when they convey knowledge in one way that they consider every student will understand; there is also a drawback if a learner gets used to accumulate a piece of knowledge in his learning style, he will refuse other teaching approaches when he studies in a group of students (Alan Pritchard, 2009, p. 55). That is why it is essential for teachers to implement all the possible learning styles in the classroom.

Table 1 Ways of learning

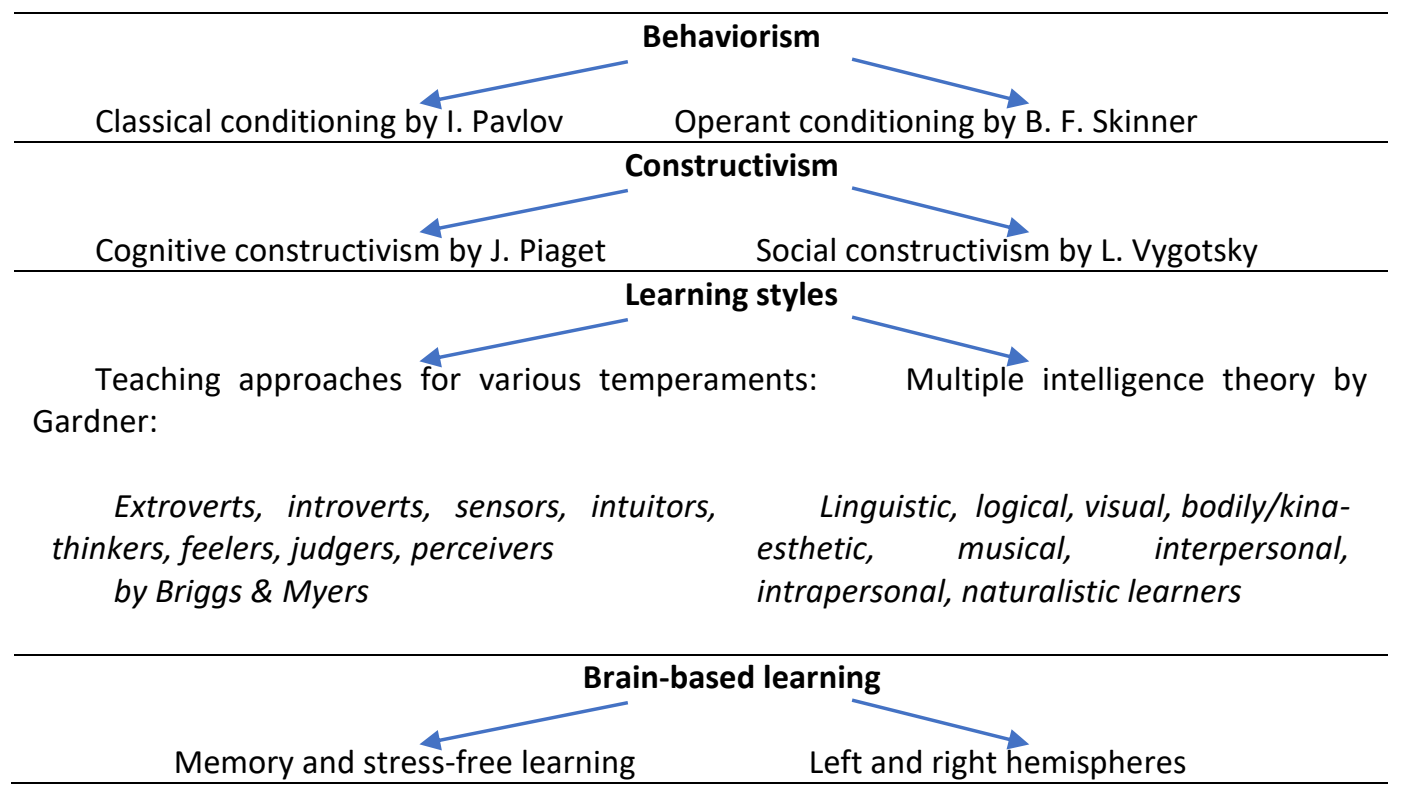

Brain-based learning. Learning takes place in the brain. It is apparent that the brain is divided into two hemispheres: left and right. The brain divides learning between visual and verbal tasks. Reading and learning from the context take place in the left hemisphere whereby the right one enables learning via visual means (Döring, K./Ritter-Mamczek, p. 161, 1997). Successful teachers engage students in both learning tasks in order to generate both sides of the brain. They should also pay attention to the memory activities which should be meaningful in the learning context. O'Keefe and Nadel's (1978) model describes taxon/locale and spatial/autobiographical types of memory. The first type is motivated by rewards and punishments; the second one is related to associations, especially when a person experiences some events. 
To organize a stress-free environment is very important for both teachers and students. From the historical perspective, it is obvious that teachers were strict with their learners and used some kind of punishment. Stress is a kind of emotion that slows down the learning process. Reavis (1999) tried to explain in his book called 'The Animal School' that teachers should pay attention to each student's ability and not force students to do what they are not capable of. Each student is an individual and unique. The learning process should be focused on the student's learning style and create an atmosphere where students can develop their strengths by using their abilities. Learning is a social process, it should be organized in the way of interaction; the content of learning materials should be meaningful for students and related to their previous knowledge to get good learning outcomes. Table 2 indicates philosophical assumptions in different learning ways with implications for practice by John W. Creswell (2013).

Table 2 Philosophical Assumptions with Implications for Practice by John W. Creswell (2013)

\begin{tabular}{|c|c|c|c|}
\hline Assumption & Questions & Characteristics & Implication for Practice \\
\hline Ontological & $\begin{array}{l}\text { Are behavioral } \\
\text { learning } \\
\text { methods widely } \\
\text { used in e- } \\
\text { learning } \\
\text { environments? }\end{array}$ & $\begin{array}{c}\text { Behavioral learning is a change in } \\
\text { knowledge and skills in a positive } \\
\text { way. As a result, a student will learn } \\
\text { something new in order to achieve his } \\
\text { own goal. The learning process is } \\
\text { conditioned by reinforcement and } \\
\text { habit. }\end{array}$ & $\begin{array}{l}\text { Immediate feedback given after } \\
\text { reading a text plays a key role in } \\
\text { computer-based education system; a } \\
\text { student answers several questions } \\
\text { online and gets the learning outcomes } \\
\text { at once without waiting for a teacher } \\
\text { next time in the classroom. }\end{array}$ \\
\hline Epistemological & $\begin{array}{l}\text { What is a } \\
\text { teacher's role in } \\
\text { cognitive } \\
\text { development } \\
\text { while students } \\
\text { are studying? }\end{array}$ & $\begin{array}{l}\text { Learning is a mental process. It } \\
\text { should be always developed by a } \\
\text { learner. Learners should be engaged } \\
\text { in the learning process by being active } \\
\text { and interested or motivated to learn } \\
\text { something new and accumulate new } \\
\text { information to the current one. } \\
\text { Additionally, more knowledgeable } \\
\text { teachers or trainers play a key role in } \\
\text { cognitive development in order to } \\
\text { encourage students in the right way } \\
\text { of learning. }\end{array}$ & $\begin{array}{l}\text { Blended learning style might be an } \\
\text { excellent example of cognitive } \\
\text { development of students. In the } \\
\text { classroom, they will be engaged in the } \\
\text { proximal development by their } \\
\text { teachers and out of the classroom, } \\
\text { students will explore for more } \\
\text { information to solve the assigned } \\
\text { academic task; here the information } \\
\text { technology is of great importance if } \\
\text { used properly. }\end{array}$ \\
\hline Axiological & $\begin{array}{l}\text { What is a role of } \\
\text { the brain in } \\
\text { learning? }\end{array}$ & $\begin{array}{l}\text { The brain controls all the process } \\
\text { which takes place in our body. It is } \\
\text { believed that the brain is divided into } \\
\text { left and right hemispheres and each } \\
\text { of them is responsible to learn } \\
\text { specific academic tasks. }\end{array}$ & $\begin{array}{l}\text { Since each part of the brain works } \\
\text { differently, teachers should include all } \\
\text { the academic tasks in their curriculum } \\
\text { which operate students' brains for } \\
\text { beneficial learning. }\end{array}$ \\
\hline Methodological & $\begin{array}{l}\text { What is the } \\
\text { value of } \\
\text { multiple } \\
\text { teaching } \\
\text { approaches? }\end{array}$ & $\begin{array}{l}\text { A sensitive teacher will convey } \\
\text { knowledge to students in the way of } \\
\text { the comfort zone. Students will be } \\
\text { able to demonstrate and develop } \\
\text { their strengths in the learning } \\
\text { process. }\end{array}$ & $\begin{array}{l}\text { Nowadays, e-learning } \\
\text { environments may be a good example } \\
\text { of learning in the comfort zone. } \\
\text { Students may study at their pace at } \\
\text { any time. }\end{array}$ \\
\hline
\end{tabular}

E-learning environments. The XX-th century changed learning ways from traditional campus-based education to e-learning (electronic learning). It is obvious that the e-learning system has become functional because of the current global pandemic COVID 19 which has been influencing the Kazakhstani education system as well since March 2020. All education systems switched from class-based learning to distance education without educational institutional preparation (Arlinwibowo et al., 2020). Flindt (2005) indicated three stages of e-learning: stage 1 is related to learning context in different online forms such as HTML or PDF; stage 2 refers to communication elements such as synchronous (video, telephone, or web conference) and asynchronous (emails); stage 3 is supported by teachers via information communication technology. For 
instance, EF English Live platform is considered to be the world's most advanced cloud based school (Figure 1). Digital education has been available to a large number of students in comparison with traditional education for affordable prices or even for free charge. In addition, e-learning materials have been advanced from simple to complex academic tasks. The most valuable feature of e-learning is that students will experience different social-cultural communication. As can be seen from Figure 1, students from the world have access to this platform and participate in virtual learning, and a teacher manages the e-learning environment. Students have an opportunity to choose their own methods of learning. In the virtual classroom, the learning atmosphere is almost the same as at face-to-face lessons. There are multiple functional buttons for raising hands if there is a question or to listen if a student does not want to speak. There is also an instant chat display which can replace the traditional blackboard.

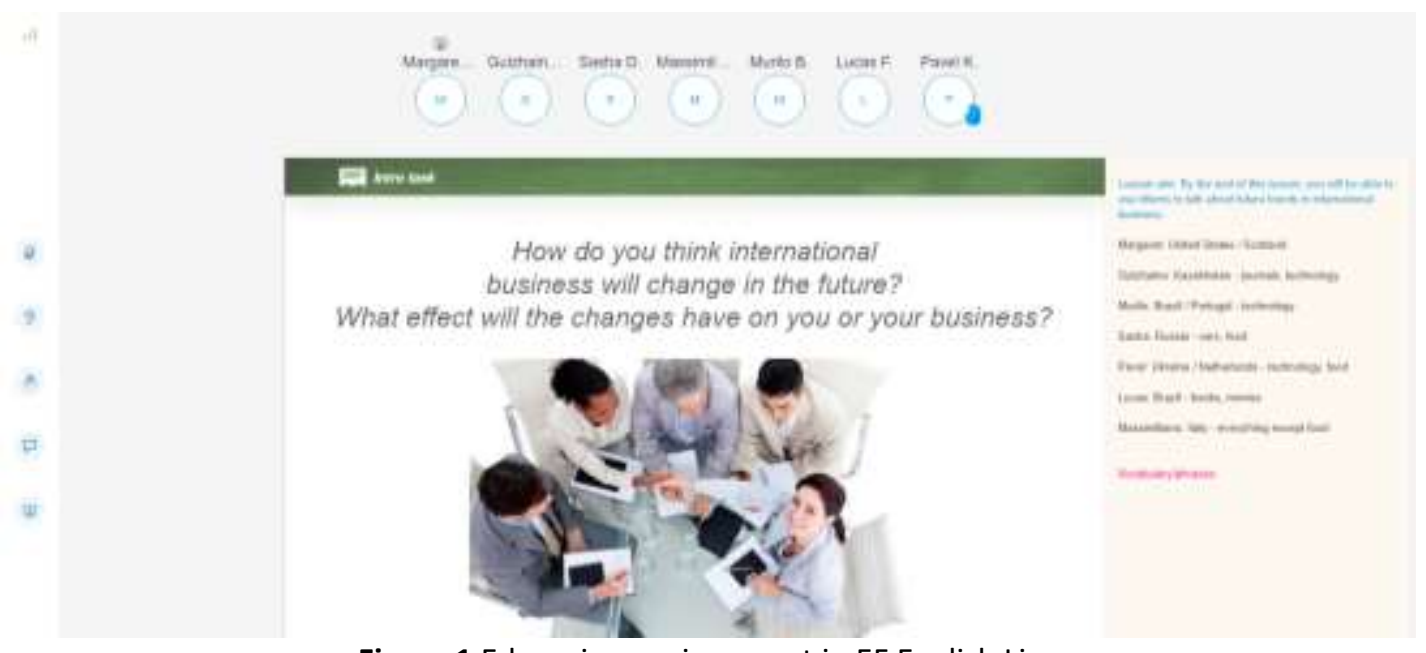

Figure 1 E-learning environment in EF English Live

E-learning related to behaviorism. Programmed instruction, introduced by behaviorist B.F. Skinner, is a system whereby a student learns on his own via specially prepared books or equipment without a teacher. The goal of this program was to free teachers from burdensome drills and repetitive problem-solving inherent in teaching basic academic subjects like spelling, arithmetic, and reading.

Skinner focused his programmed instruction on the principle of operant conditioning, which theorized that learning takes place when a reinforcing stimulus is presented to reward a correct response (Bower \& Hilgard, 1981). One of the advantages of e-learning is that a student gets immediate feedback on the tasks. It was Pressey who first emphasized the importance of immediate feedback in education and proposed a system that enables students to learn at his own pace. Pressey also pointed out that teaching machines increase effective learning outcomes (Skinner, 1958, p. 969). There are two types of learners: fast and slow. They were not taught equally enough at traditional lessons, and e-learning environments permit each student to learn at his rate which is another upside of digital education. E-learning advantages are outweighed by these or other considerations in the way of individual learning.

Online games in the classroom. Recent research by Ellison et al. (2016) has shown that online games develop collaborative learning, critical thinking, and problem-solving skills among youth. Applying online games such as in schools is significant in the digital era. For instance, students benefit from Minecraft to enhance learning activities in science, technology, architecture, physics, engineering, math and as well as linguistic skills such as writing, speaking, listening and reading. Additionally, teachers benefit from using Minecraft as a teaching tool in the classroom to increase academic engagement with students. Online games have the potential to push a player to think cognitively and to interact socially with others. Players creatively build their new virtual world; they participate in complicated problem-solving tasks. This study recommends online games to be implemented in the classroom as a teaching and learning tool for motivation and to improve academic activities. As Piaget (1951) stated that play is a significant mediator for learning and socialization.

"My hypothesis is that in the future the gaming industry will blow up the whole world. For example, with VR glasses, you can immerse yourself in the virtual world, and feel the essence of the game. For instance, Figure 2 was built by me and I got experience in how to work on 
architecture. In the future, you will be able to enter the game, and feel the meaning of the game, feel and sense different things. For example, how it rains or you feel cold and warm, you can get injured in shooters or feel the emotions of characters. Adults say that games do not develop thinking, that games take time and disturb functions of the brain, but I think that if you create a game that would develop children with cerebral palsy, then the world would already open up the future. I got this conclusion from my experience in video games, for 6 years I have played different games. At first, I played Minecraft, and after nine years I started playing shooters like Critical ops created by the Finnish developers of Critical Forse, after that, I switched to CSGO. This is how I got my 6 years of experience in the field of video games. A lot of new things should be created that people like and develop their thinking skills and abilities like in Minecraft or discover leadership skills like in CSGO", shares a pupil, Farid Vafazov, with his experience on online games from I.V. Panfilov Kazakh-Russian Specialized School-Lyceum №54 in Almaty, Kazakhstan.

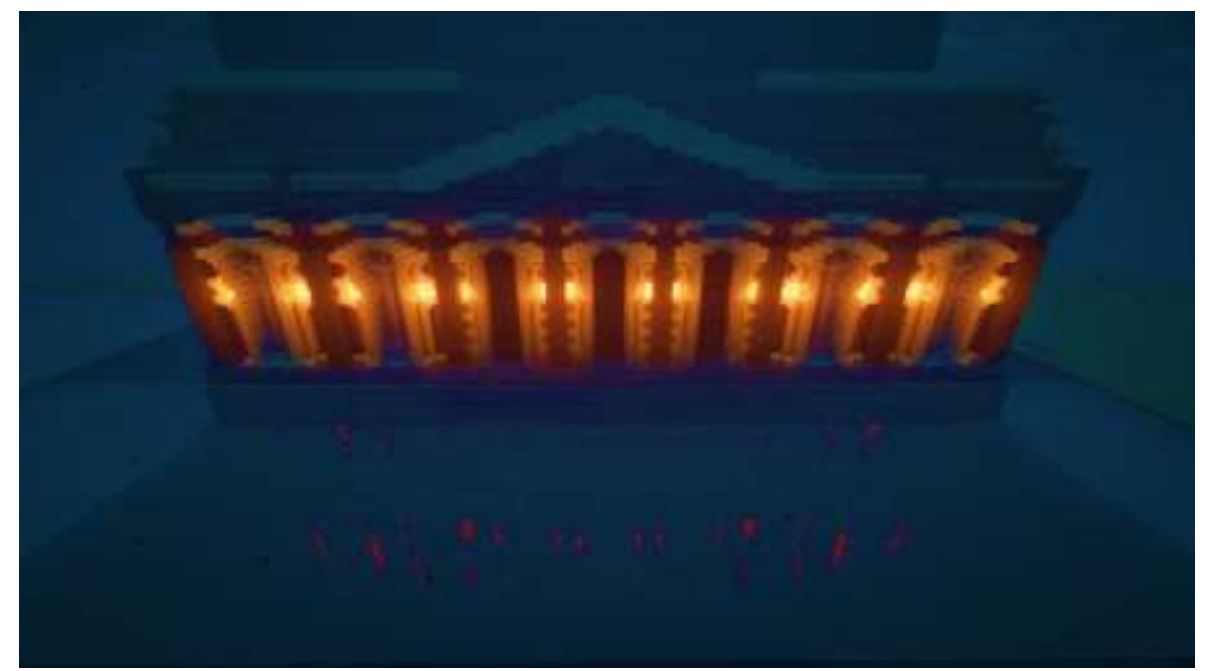

Figure 2 A house built by a gamer in Minecraft online games

E-learning related to cognition and brain. The latest cognitive theories confirm that the brain is identical to the computer. The cognitive theories are divided into three streams such as thinking psychology, action theory approach, and neuroscience learning research. The thinking psychology emphasizes that there is not only language, logic, perception, memory, and problem analysis in this theory but also meaning and comprehension play a key role (Flindt, p. 66, 2005). The action theory approach is related to psychological internal and external actions. According to Leontjew (1977), internal action is a reflection of external action. These actions require a cognitive analysis and exact realization notes, action strategies, and knowledge about what, how, why, etc. this action will be processed (Rosemann, 1974). It is apparent that according to the current neuroscience learning research, the brain is a central organ for learning something new. Nerv cells are specialized on the information process and its storage in the brain. Regardless of our needs, we always learn something new (Spitzer, p.18, 2003). Younger students learn faster than the elder students who will learn everything based on their life experience.

E-learning materials are widely used in education fields such as linguistics, psychics, aviation, psychology, medicine or business, etc. For instance, there are different chatbots that are beneficial to use for people who feel stressed or depressed. Chatbots can support communication with people. A "chatbot" or "bot" is an artificially intelligent software program that uses natural language processing to simulate an intelligent conversation with end-users via auditory or textual methods. Many bots are programmed to act like humans so that when a person interacts with them it feels like asking another person for help in communication (Patent, US10025567B2, 2018-2037). E-learning materials are very beneficial in the learning process. For example, educational simulations enable students to conduct an experiment in the virtual environments that they learned from the theory.

"Simulations are a great way to teach students to make decisions with ambiguity because they've taken all kinds of courses over the years, they've been tested, sometimes with cases, sometimes using regular tests; but this allows them to use the full range and make decisions," says John Kraft, Susan Cameron Chair of International Business, Warrington College of Business, 
University of Florida / Visiting faculty, Aalto Mikkeli (https://www.cesim.com/).

E-learning environments create lessons interactive. Knowledge is integrated from many different sources when students are learning something. Regular subject-based courses are narrower and they may focus on the textbook or lecture. But in e-learning, students will try to pull together rather uncertain information from different sources via the internet.

E-learning environments might be implemented in the technical engineering industries as a simulator. Developed research technologies obtained by professional researchers in real time can be applied in digital environments for the purpose to avoid the danger of chemical reactions (Kenzhaliev et al., 2014; Kenzhaliev et al., 2017). Such an approach not only protects human beings from dangerous metal reactions and also increases future young engineer researchers' competency (Kassymova, 2018). Students can master their skills in the online simulators before starting working in the laboratories (Kenzhaliev et al., 2017).

\section{Research findings}

Having analyzed ways of learning, the authors offer five learning approaches as a result of this study. This requires students to be active, engaged in the learning process, to increase previous knowledge, to have needs and intrapersonal motivation for self-development; learning takes place in the brain and teachers should ensure that the curriculum should include different academic tasks for the left and right hemispheres operations.....

Learning appchoach includes the following stages for students:

$>$ To be active

$>$ To be engaged in the learning process

$>$ To increase previous knowledge

$>$ To explore the situation

$>$ To be motivated

The trend topic of e-learning has undergone an enormous change in recent years. If you look from the beginnings of e-learning to the present, from a technical point of view there is a change from simple behaviorist-oriented learning programs to today's complex learning platforms with online learning communities such as web classes, database connections, and interactive learning content. Researchers predicted in 2005 that the concept of e-learning would evidently embark on a new campaign of conquest in the next few years in Europe. However, success only seems possible if one knows the mistakes of the past and does not repeat them. The problems of the previous e-learning included technical problems, lack of involvement and relevance for everyday work, lack of social contacts, problems with on-the-job learning, badly designed and pedagogically and didactically immature e-learning courses and inadequate selflearning skills of the participants (Flindt, 2005, p. 354-355). In this study, it is obvious that e-learning environments are dramatically improved and benefit learners with the convenience of learning.

Another study (2018) conducted an experiment on cognitive development in e-learning and concluded that Bloom's taxonomy is an incredibly powerful tool at all levels of the education system in terms of elearning environments to develop students' behavior and get a better learning outcome. The basic goal of the e-learning industry is to make the teaching and learning process easy, active, and enjoyable. Such an approach enables students to become problem solvers and critical thinkers which is the top aim of the Blooms' taxonomy concept (Ratniece, 2018).

Nevertheless, use of the internet for learning or e-learning also cannot be separated from various deficiency. First, lack of interaction between teachers and students or even between students themselves. This lack of interaction can be detaining for achieve the learning objection. Second, students who do not have high motivation will be left behind, even can be fail. Third, not all places have internet facilities. According to (Kahiigi, Ekenberg, Hansson, Tsubira, Danielson, 2008), There is emerging issues within the higher education context: (1) identifying pedagogies underlying online courses. (2) improving ICT (Information and Communication Technology) skills for both teacher and student. (3) Technology use mostly for teacher that being too traditional in their teaching strategy and unwillingness to adopt change. (4) Management support, because e-Learning initiatives require full commitment and support from management for their operationalization and sustainability. 


\section{Conclusions}

Learning is a cognitive process and it cannot be seen or touched. Learning outcomes are measured by an education assessment system. Telling is not teaching, students should be actively and socially engaged in the learning process. It is obvious that without active social engagement and motivation, effective learning for students is far less likely to be good learning outcomes regardless of the form of education, age, or sex of students whether it is an online or traditional lesson or self-study. In addition, there are prospects in online games, they should be studied properly in order to discover a lot of new things in the online education industry. Learning should take place in stress-free environments since learning is a social brainbased process; it should be also flexible and offer multiple opportunities for students to work alone or in the team.

Cite this article as: Kassymova, G.K.; Vafazov, F.R.; Pertiwi, F.D.; Akhmetova, A.I.; Begimbetova, G.A. (2021). Upgrading Quality of Learning with E-Learning System. Challenges of Science. Issue IV, 2021, pp. 26-34. https://doi.org/10.31643/2021.04

\section{References}

Alan Pritchard (2009). Ways of learning. Learning theories and learning styles in the classroom. Second edition published by Routledge, London and New York.

Arlinwibowo J., Retnawati H., Kartowagiran B., Kassymova G.K. (2020). Distance learning policy in Indonesia for facing pandemic COVID-19: School reaction and lesson plans. Journal of Theoretical and Applied Information Technology, 98 (14), 2828-2838

Arpentieva M.R..; Retnawati H.; Akhmetova T.A.; Azman M.N.A.; Kassymova G.K. (2021). Constructivist approach in pedagogical science. Challenges of Science. Issue IV, 2021, pp. 12-17. https://doi.org/10.31643/2021.02

Bower, G. H., \& Hilgard, E. R. 1. (1981). Theories of learning. 5th ed. Englewood Cliffs, N.J.: Prentice-Hall.

Briggs, K. and Myers, I. B. (1975) The Myers-Briggs Type Indicator. Palo Alto, CA: Consulting Psychologist Press.

Candra, \& Retnawati, H. (2020). A Meta-Analysis of Constructivism Learning Implementation towards the Learning Outcomes on Civic Education Lesson. International Journal of Instruction, 13(2), 835-846. https://doi.org/10.29333/iji.2020.13256a

Döring, K./Ritter-Mamczek, B. (1997). Lehren und Trainieren in der Weiterbildung. Ein praxisorientierter Leitfaden. 6. Aufl., Weinheim.

Ellison T. L., Evans J. N., Pike J. Minecraft, teachers, parents, and learning: What they need to know and understand. School Community Journal, 2016, Vol. 26, Issue 2. P.25-43

Elyas Hadi, Ananda. (2018). Penggunaan Model Pembelajaran E-Learning dalam Meningkatkan Kualitas Pembelajaran. Warta Journal. Edition 56.

Flindt N., (2005). Inaugural-Dissertation zur Erlangung des Doktorgrades, E-learning, theoriekonzepte und Praxiswirklichkeit. Heidelberg.

Gardner, H. (1993) Multiple Intelligences: The Theory in Practice. New York: Basic Books

John W. Creswell (2013). Qualitative inquiry and research design: choosing among five approaches. Third edition published by Sage, Los Angeles, London, New Delhi, Singapore and Washington DC, p. 21

Kahiigi K. Evelyn, Ekenberg L, Hansson H, Tsubira F.F, Danielson M. (2008). Exploring the E-Learning State of Art. Electronic Journal e-Learning Volume 6 Issue 22008 (77-88).

Kassymova G. (2018). Competence and its implications. Challenges of Science. https://doi.org/10.31643/2018.063

Kassymova G., Akhmetova A., Baibekova M., Kalniyazova A., Mazhinov B., Mussina S. (2020). E-Learning Environments and Problem-Based Learning. International Journal of Advanced Science and Technology, 29(7s), 346 - 356. Retrieved from http://sersc.org/journals/index.php/IJAST/article/view/9447

Kassymova G., Bekalaeva A., Yershimanova D., Flindt N., Gadirova T. and Duisenbayeva Sh. (2020). E-Learning Environments and Their Connection to the Human Brain. International Journal of Advanced Science and Technology, 29(9s), 947 - 954. Retrieved from http://sersc.org/journals/index.php/IJAST/article/view/13359

Kassymova G.K., Kenzhaliyev O.B., Kosherbayeva A.N., Triyono B.M., Ilmaliyev Zh.B. (2020), E-Learning, Dilemma and Cognitive Competence. Journal of Talent Development and Excellence. Vol. 12 No. 2s., p. 3689-3704. Retrieved from: http://www.iratde.com/index.php/jtde/article/view/1276/975

Kenzhaliev B.K., Berkinbayeva A.N., Suleimenov E.N. (2014). Using sulfur graphite electrode for extracting metals from refractory materials. Proceedings of the 65th Annual Meeting of the International Society of Electrochemistry Ubiquitous Electrochemistry, (EUE'14), Lausanne, Switzerland.

Kenzhaliev B.K., Kvyatkovsky S.A., Kozhakhmetov S.M., Sokolovskaya L.V., (2018). Depletion of waste slag of balkhash copper smelter. Kompleksnoe Ispol'zovanie Mineral'nogo syr'â = Complex Use of Mineral Resources, 3, 45-53.

Kenzhaliev B.K., Surkova T.Y., Yulusov S.B., Pirmatov E.A., Dulenin A.P. (2017). Polucheniye kontsentrata redkozemel'nykh elementov iz otkhodov i promproduktov uranovoy promyshlennosti [Obtaining a concentrate of rare earth elements from waste and industrial products of the uranium industry] Kompleksnoe Ispol'zovanie Mineral'nogo syr'â = Complex Use of 
Mineral Resources, Issue 1, pp. 70-77. (in Rus.).

Kenzhaliyev O.B., Kassymova G.K., Triyono B.M., Azman M.N.A., Ilmaliyev Zh.B. (2020), Case Study: E-Learning Via EF English Live as A Means to Improve Competitiveness Among University Staff. In The Framework of Portfolio Project Management. Journal of Talent Development and Excellence. Vol. 12 No. 2s., p. 3705-3720. Retrieved from: http://www.iratde.com/index.php/jtde/article/view/1277/976

Lai, S. C., \& Lin, C. Y. (2020). The effect of the use of multimedia technology on year three student's Chinese vocabulary learning. Muallim Journal of Social Sciences and Humanities, 4(2), 87-92. https://doi.org/10.33306/mjssh/65

Leontjew, A. N. (1977). Tätigkeit, Bewußtsein, Persönlichkeit. Stuttgart. P.17.

Mustapha, R., Sadrina, Mat Nashir, I., bin Azman, M. N. A., \& Hasnan, K. A. (2019). Assessing the Implementation of the ProjectBased Learning (PJBL) in the Department of Mechanical Engineering at a Malaysian Polytechnic. Journal of Technical Education and Training, 12(1). Retrieved from https://publisher.uthm.edu.my/ojs/index.php/JTET/article/view/3161

O'Keefe, J. and Nadel, L. (1978) The Hippocampus as a Cognitive Map. New York: Oxford University Press.

Patent US10025567B2 invented by Barath Balasubramanian, Ashwin Sathya Raghunathan, Jade D. Naaman, Daniel J. Kappes (20182037). United States.

Piaget J., Play, dreams, and imitation in childhood. New York, NY: W. W. Norton, 1951.

Piaget, J. (1936). The origins of intelligence in children. New York: W.W Norton and Company.

Ratniece D. Cognitive Development in Active eLearning. International Journal of Engineering \& Technology. 7 (2.28), 2018, p. 53-57. Reavis G. (1999) The Animal School. Published May 1st 1999 by Crystal Springs Books, UK.

Rosemann, H. (1974). Lernen, Behalten und Denken: Lerntheorien: Konditionierung, Einsicht, Orientierung, Handlungstheorie, Begriffs- u. Bedeutungslernen, in: Arbeitshefte für Psychologie/Rosemann, H., Berlin. P.55.

Rosenberg J, Marc. (2002). E-LearningL Strategies for Delivering Knowledge in The Digital Age. Performance Improvement, Vol. 14. No. 5

Shanty, S., Kiong, T. T., Jailani, M. Y., Heong, Y. M., Mimi Mohaffyza, M., Widad, O., Mohamed Nor Azhari, A., Zaliza, H., \& Nurulwahida, A. (2018). Thinking Style Pattern Among Design and Technology Teachers in Malaysia. Journal of Technical Education and Training, 11(3). Retrieved from https://publisher.uthm.edu.my/ojs/index.php/JTET/article/view/3119

Skinner, B. F. (1958) Teaching Machines. Science, 24 October, 1958. Volume 128, Number 3330, p. 969-977.

Spitzer, M. (2003). Lernen. Gehirnforschung und die Schule des Lebens, korr. Nachdruck. Heidelberg/Berlin.

Suartama, I, Kadek. (2014). E-Learning: Konsep dan Aplikasinya. Universitas Pendidikan Ganesha, Indonesia.

Vygotsky, L.S. (1978). Mind in society. Cambridge: Harvard University Press.

Woolfolk, A. E. (1993) Educational Psychology. $5^{\text {th }}$ edition. Needham Heights, MA: Allyn and Bacon. 